\title{
Long-term macrobioerosion in the Mediterranean Sea assessed by micro-computed tomography
}

\author{
Claudia Färber $^{1}$, Jürgen Titschack ${ }^{1,2}$, Christine Hanna Lydia Schönberg ${ }^{3,4}$, Karsten Ehrig $^{5}$, Karin Boos $^{2}$, \\ Daniel Baum $^{6}$, Bernhard Illerhaus ${ }^{5}$, Ulla Asgaard ${ }^{7}$, Richard Granville Bromley ${ }^{7}$, André Freiwald ${ }^{1}$, and \\ Max Wisshak ${ }^{1}$ \\ ${ }^{1}$ Senckenberg am Meer, Abteilung Meeresforschung, Südstrand 40, 26382 Wilhelmshaven, Germany \\ ${ }^{2}$ MARUM, Center for Marine Environmental Sciences, University of Bremen, Leobener Straße, 28359 Bremen, Germany \\ ${ }^{3}$ Oceans Institute, University of Western Australia, Crawley, WA 6009, Australia \\ ${ }^{4}$ Western Australian Museum, Welshpool, WA 6106, Australia \\ ${ }^{5}$ Bundesanstalt für Materialforschung und -prüfung (BAM), Unter den Eichen 87, 12205 Berlin, Germany \\ ${ }^{6} \mathrm{ZIB}$, Zuse Institute Berlin, Takustraße 7, 14195 Berlin, Germany \\ ${ }^{7}$ Department of Geography and Geology, University of Copenhagen, 1350 Copenhagen K, Denmark
}

Correspondence to: Claudia Färber (claudia.faerber@senckenberg.de)

Received: 18 December 2015 - Published in Biogeosciences Discuss.: 26 January 2016

Revised: 6 May 2016 - Accepted: 15 May 2016 - Published: 15 June 2016

\begin{abstract}
Biological erosion is a key process for the recycling of carbonate and the formation of calcareous sediments in the oceans. Experimental studies showed that bioerosion is subject to distinct temporal variability, but previous long-term studies were restricted to tropical waters. Here, we present results from a 14-year bioerosion experiment that was carried out along the rocky limestone coast of the island of Rhodes, Greece, in the Eastern Mediterranean Sea, in order to monitor the pace at which bioerosion affects carbonate substrate and the sequence of colonisation by bioeroding organisms. Internal macrobioerosion was visualised and quantified by micro-computed tomography and computeralgorithm-based segmentation procedures. Analysis of internal macrobioerosion traces revealed a dominance of bioeroding sponges producing eight types of characteristic Entobia cavity networks, which were matched to five different clionaid sponges by spicule identification in extracted tissue. The morphology of the entobians strongly varied depending on the species of the producing sponge, its ontogenetic stage, available space, and competition by other bioeroders. An early community developed during the first 5 years of exposure with initially very low macrobioerosion rates and was followed by an intermediate stage when sponges formed large and more diverse entobians and bioerosion rates increased. After 14 years, $30 \%$ of the block volumes were
\end{abstract}

occupied by boring sponges, yielding maximum bioerosion rates of $900 \mathrm{~g} \mathrm{~m}^{-2} \mathrm{yr}^{-1}$. A high spatial variability in macrobioerosion prohibited clear conclusions about the onset of macrobioerosion equilibrium conditions. This highlights the necessity of even longer experimental exposures and higher replication at various factor levels in order to better understand and quantify temporal patterns of macrobioerosion in marine carbonate environments.

\section{Introduction}

Bioerosion, the erosion of hard substrate by living organisms (Neumann, 1966), generally comprises (i) internal microbioerosion by boring cyanobacteria, algae, and fungi; (ii) internal macrobioerosion by boring sponges, worms, and bivalves; and (iii) external bioerosion by grazing gastropods, echinoids, and fish (e.g. Glynn, 1997; Tribollet et al., 2011). Experimental studies showed that the succession of bioerosion agents is subject to distinct temporal variability: under favourable conditions, microborers can reach stable communities within 1 year of exposure (Grange et al., 2015; Tribollet and Golubic, 2005), whereas establishment of mature communities of macrobioeroders may take several years to form mature communities (e.g. Chazottes et al., 2002; Kiene 
and Hutchings, 1992, 1994; Pari et al., 1998, 2002; Tribollet and Golubic, 2005). Most bioerosion experiments were conducted over a period of only 1-2 years, giving a detailed picture on microbioerosion in different geographical settings (e.g. Kiene, 1988; Vogel et al., 1996, 2000; Wisshak, 2006; Wisshak et al., 2010, 2011). Experimental studies on the succession of macrobioeroders were previously limited to tropical coral reef systems and commonly lasted about 48 years (Carreiro-Silva and McClanahan, 2012; Kiene and Hutchings, 1992, 1994; Pari et al., 2002). The longest experiments have been conducted over 9 years at the Great Barrier Reef (Kiene and Hutchings, 1992) and 13 years at Jamaica (Scott et al., 1988). To date, no experimental data on longterm bioerosion from non-tropical settings are available, but they would constitute important information for evaluating global patterns of bioerosion and for modelling future impacts of bioerosion. This is particularly relevant since bioerosion is considered to increase with ongoing ocean acidification (Tribollet et al., 2009), a trend that is especially true for bioeroding sponges (e.g. Fang et al., 2013; Wisshak et al., 2012, 2013, 2014), with potentially detrimental effects on carbonate-dominated ecosystems (Kennedy et al., 2013).

In the Mediterranean Sea, bioerosion affects sensitive ecosystems such as limestone coasts, deposits of coralline algae, and cold-water coral reefs, as well as molluscs in aquaculture, submerged man-made materials, and artefacts (see Schönberg and Wisshak (2014) for a review). Experimental data on Mediterranean bioerosion are only available in form of short-term observations on microendoliths (Färber et al., 2015; Le Campion-Alsumard, 1979). Here, we present results from a long-term bioerosion experiment that was carried out over 14 years along the limestone rocky shore of Rhodes (Greece) in order to analyse the succession of bioeroders in the Eastern Mediterranean Sea. A preliminary summary on macroscopic observations during the first 6 years was provided by Bromley et al. (1990). For the visualisation of internal macrobioerosion traces and quantification of macrobioerosion rates, micro-computed tomographic analysis was chosen as a non-destructive approach. Computed tomography is increasingly used to visualise bioerosion traces in three dimensions (Beuck et al., 2007, 2008; Bromley et al., 2008; Schönberg and Shields, 2008), but quantitative approaches are still scarce and comparatively new (Crook et al., 2013; DeCarlo et al., 2015; Silbiger et al., 2014, 2016). Aim of this paper is (i) to introduce a novel approach to visualise and quantify internal bioerosion using computer-algorithm-based segmentation procedures, (ii) to provide an inventory of macrobioerosion traces, (iii) to identify trace making boring sponges through spicule analysis, and (iv) to assess the long-term development of bioerosion rates and ontogenetic development of sponge borings in terms of a possible onset of macrobioerosion equilibrium conditions.

\section{Material and methods}

\subsection{Experimental design}

The settlement experiment was carried out in the vicinity of four limestone cliffs at the eastern and western coast of the island of Rhodes, Greece (Fig. 1): (i) at the southern and eastern edge of Ladiko Bay $\left(36^{\circ} 19^{\prime} 5^{\prime \prime} \mathrm{N}, 28^{\circ} 12^{\prime} 17^{\prime \prime} \mathrm{E}\right.$; $36^{\circ} 19^{\prime} 10^{\prime \prime} \mathrm{N}, \quad 28^{\circ} 12^{\prime} 29^{\prime \prime} \mathrm{E}$ ), (ii) south of Kolimbia $\left(36^{\circ} 14^{\prime} 26^{\prime \prime} \mathrm{N}, \quad 28^{\circ} 9^{\prime} 44^{\prime \prime} \mathrm{E} ; \quad 36^{\circ} 14^{\prime} 21^{\prime \prime} \mathrm{N}, \quad 28^{\circ} 9^{\prime} 47^{\prime \prime} \mathrm{E}\right)$, (iii) north of St. Paul's Bay near Lindos $\left(36^{\circ} 5^{\prime} 17^{\prime \prime} \mathrm{N}\right.$, $28^{\circ} 5^{\prime} 20^{\prime \prime} \mathrm{E}$ ), and (iv) in Pyrgos ( $36^{\circ} 10^{\prime} 10^{\prime \prime} \mathrm{N}, 27^{\circ} 43^{\prime} 55^{\prime \prime} \mathrm{E}$ ). All localities were characterised by limestone rock ground or boulder fields and were free from local pollution. Annual monitoring in October showed no indication of interference of the experiment by human activities.

The original description of the experiment is provided in Bromley et al. (1990) and is summarised here as follows: between 1982 and 1989, experimental blocks were deployed in water depths between 3 and $17 \mathrm{~m}$. The blocks were of marble and micritic limestone, and respective lithologies were confirmed by petrographic thin sections (Table 1). Initially, smaller blocks $(1-3 \mathrm{~kg})$ were placed directly on the sea floor, but many of these were lost during winter storms in the first year. Accordingly, larger blocks were laid out $(5-30 \mathrm{~kg})$ and smaller blocks were tied securely to iron or plastic frames to increase their stability. However, except in the most turbulent sites, anchoring of blocks was avoided to simulate natural conditions as closely as possible. Between 1982 and 1996 each year some blocks were retrieved, all by skin diving and using floatation devices. Recovered blocks were rinsed in fresh water and soft epiliths were removed. The blocks were subsequently photographed and dried.

\subsection{Micro-computed tomography}

Internal bioerosion in the blocks was investigated by microcomputed tomographic analysis (micro-CT). From the whole inventory of 46 recovered blocks, 12 were chosen from different depths ( 3 to $17 \mathrm{~m}$ ) and exposure times (1 to 14 years), all with a surface area of $11 \times 11 \mathrm{~cm}$ or larger. Most of the blocks showed no evidence for having been dislocated during the experiment; however, some had slightly moved and for some blocks the information about recovery date and/or water depth was incomplete (Table 1). This was reviewed case by case, and ultimately the latter blocks were included in the study. In order to yield a spatial resolution of about $70 \mu \mathrm{m}$, the chosen blocks were cut with a rock saw to a uniform surface area of $10 \times 10 \mathrm{~cm}$. The thickness of these blocks varied between 2 to $5 \mathrm{~cm}$ but, to keep mechanical destruction as small as possible, adjusting the thickness was avoided at this stage. The 7-year block was cut into three such blocks as replicates to obtain an impression of the spatial variability of bioerosion within a single block. From blocks that were large enough to be cut into several subsamples, replicates 
Table 1. Metadata of experimental blocks deployed during the experiment and analysed via micro-computed tomography (E is east, $\mathrm{W}$ is west, $\mathrm{Ma}$ is marble, $\mathrm{Mi}$ is micritic limestone).

\begin{tabular}{|c|c|c|c|c|c|c|}
\hline $\begin{array}{l}\text { Exposure } \\
(\mathrm{yr})\end{array}$ & Site & Coast & $\begin{array}{l}\text { Water depth } \\
\text { (m) }\end{array}$ & Deployment & Recovery & $\begin{array}{l}\text { Block } \\
\text { lithology }\end{array}$ \\
\hline 1 & Lindos & $\mathrm{E}$ & $3-8$ & 21 Oct 1982 & 25 Oct 1983 & $\mathrm{Ma}$ \\
\hline 1 & Pyrgos & W & $3-6$ & 20 Oct 1982 & 26 Oct 1983 & $\mathrm{Ma}$ \\
\hline 2 & Pyrgos & W & 8 & 26 Oct 1983 & 15 Oct 1985 & $\mathrm{Ma}$ \\
\hline 3 & Ladiko & $\mathrm{E}$ & $3-4$ & 28 Oct 1983 & 22 Oct 1986 & $\mathrm{Ma}$ \\
\hline 4 & Lindos & $\mathrm{E}$ & $16-17$ & 19 Oct 1982 & 19 Oct 1986 & $\mathrm{Mi}$ \\
\hline 4 & Ladiko & $\mathrm{E}$ & 3.5 & 28 Oct 1983 & Oct 1987 & Ma \\
\hline 5 & Ladiko & $\mathrm{E}$ & 3 & 28 Oct 1983 & 14 Oct 1988 & $\mathrm{Mi}$ \\
\hline 6 & Lindos & $\mathrm{E}$ & 12 & 18 Oct 1985 & 18 Oct 1991 & $\mathrm{Ma}$ \\
\hline $7^{*}$ & Kolimbia & $\mathrm{E}$ & 3 & 17 Oct 1982 & 13 Oct 1989 & $\mathrm{Ma}$ \\
\hline 8 & Lindos & $\mathrm{E}$ & 12 & 18 Oct 1985 & 1993 & $\mathrm{Ma}$ \\
\hline $8-9$ & Pyrgos & W & 3 or 8 & 20 Oct $1982 / 83$ & 16 Oct 1991 & $\mathrm{Ma}$ \\
\hline 14 & Pyrgos & W & 7 & 20 Oct 1982 & 1996 & Ma \\
\hline
\end{tabular}

* The 7-year block was cut into three such replicates to obtain an impression of the spatial variability of bioerosion within a single block.

were randomly chosen. In this way, a total of 14 samples were produced for micro-CT analysis.

Micro-CT scanning was carried out at the Bundesanstalt für Materialforschung und -prüfung (BAM), Berlin, Germany, using the $225 \mathrm{kV}$ system (Badde and Illerhaus, 2008). An X-ray source voltage of $210 \mathrm{kV}$, a current of $90 \mu \mathrm{A}$, and a pre-filter of $1 \mathrm{~mm}$ copper was applied. Attenuation images were taken at smallest possible resolution due to specimen size. To achieve the best signal-to-noise-ratio, 2400 projections over $360^{\circ}$ with a total measuring time of $16 \mathrm{~h}$ were taken. Images were reconstructed using BAM software generated from the original Feldkamp algorithm (Feldkamp et al., 1984). The resulting voxel size was $72 \mu \mathrm{m}$.

Post-processing of micro-CT data was conducted using the Amira software edition from the Zuse Institute Berlin, ZIBAmira version 2014.51 (Stalling et al., 2005). In an initial segmentation step all encrusting epiliths on the surface of the blocks were excluded from the data set using the Segmentation Editor. Limestone substrate was distinguished from the surrounding air and organic tissue (borings were partially filled by air and organic remains of the sponges) using the marker-based Watershed segmentation module. Segmentation of the borings from the space surrounding the block was carried out with the AmbientOcclusionField module (Baum and Titschack, 2016). Resulting micro-CT images of the blocks were cropped to uniform sizes of $90 \times 90 \times 18 \mathrm{~mm}$ with the CropEditor to obtain comparable volumes. The respective volumes of substrate and bioerosion per block were quantified with the MaterialStatistics module using the results from the latter segmentation. To quantify the total surface area of each block, bioerosion and substrate were selected together and the surface was calculated using the SurfaceGen module. After removing all other surfaces except the upper surface with the SurfaceEditor, this surface area was quantified with the SurfaceStatistics module. To further evaluate the bioerosion constituents, a third segmentation step was performed based on a DistanceMap of the segmented bioerosion traces employing the ContourTreeSegmentation module to gain an automatic separation of different bioerosion traces in the blocks (threshold: 0, persistence value: 0.05; see Titschack et al., 2015). Subsequently, each trace was parameterised with the ShapeAnalysis module. The maximum trace extent defined microbioerosion patterns as $<1 \mathrm{~mm}$ and macrobioerosion patterns as $>1 \mathrm{~mm}$, following the definition by Wisshak (2012). Bioerosion rates (including micro- and macrobioerosion; $\mathrm{g} \mathrm{m}^{-2} \mathrm{yr}^{-1}$ ) were calculated by multiplying the volume of bioerosion $\left(\mathrm{cm}^{3}\right)$ with the mean density of limestone/marble of $2.7 \mathrm{~g} \mathrm{~cm}^{-3}$ (Schön, 2011) and expressing the result per surface area $\left(\mathrm{m}^{2}\right)$ per duration of exposure (years). These rates include the residual internal micro- and macrobioerosion, since the volume of substrate removed by grazers (potentially also including micro- and macrobioerosion) was impossible to quantify without a reference to the original substrate surface.

\subsection{Bioerosion inventory}

Bioerosion ichnotaxa were identified following descriptions of Bromley (1970) and Bromley and D'Alessandro (1983, 1984, 1989). Ontogenetic stages of sponge borings were classified into putative growth phases A-E according to characterisations in Bromley and D’Alessandro (1984).

\subsection{Sponge spicule analysis and species identification}

For the identification of the trace makers of Entobia cavity networks, sponge spicule preparations were made from dry sponge tissue preserved in the scanned blocks. To extract the tissue from the equivalent positions as in micro- 
CT reconstruction, the blocks were fragmented with hammer and chisel, and tissue was carefully removed with a dissecting needle. For spicule preparations sponge tissue was digested in $68 \%$ concentrated nitric acid in test tubes in a heated sand bath $\left(60-70^{\circ} \mathrm{C}\right)$ for about $2 \mathrm{~h}$, then leaving the solutions in place over night without heat application. On the next day, acid-cleaned spicules were washed three times in distilled water and dehydrated three times in laboratory-grade ethanol, each wash occurring after centrifugation and pipetting off the supernatant, taking care not to accidentally remove spicules. Spicules were then mounted for scanning electron microscopy (SEM) by drying aliquots of re-suspended spicules directly on SEM stubs, followed by sputter-coating with gold, and analysis with the SEM (VEGA3, TESCAN). In some cases, colour of the dry tissue helped with classification efforts (e.g. Christomanos and Norton, 1974), but in most cases species identification had to rely exclusively on spicules. We mostly referred to descriptions of Mediterranean bioeroding sponges by Rosell and Uriz (2002). Tylostyle measurements were obtained from 20 spicules per specimen. Spirasters and amphiasters were scarce and often broken, so that only five microscleres were measured where possible. Measurements were carried out using ImageJ v.1.48 (Rasband, 1997-2015).

\section{Results}

\subsection{Bioerosion traces}

Analysis of bioerosion patterns in the experimental blocks revealed 10 different ichnotaxa, 8 of which were attributed to the activity of excavating sponges and 2 to polychaete worms (Table 2). In respect to general patterns, the boring intensity distinctly increased with exposure time (Figs. 2-5). In blocks deployed for 2 to 5 years, superficial cavity networks were observed (Figs. 2-3). From 7 years onward, extensive three-dimensional networks had developed (Figs. 4-5). Diversity increased over time as well, with blocks containing more than one ichnospecies after 5 years (Table 2 ).

In the two blocks deployed for 1 year no macroborings were detected (Fig. 2a-b). The first distinct sponge boring was observed in the 2-year block (Fig. 2c). The trace was characterised by cylindrical chambers (about $1.4-5.1 \mathrm{~mm}$ in length, $0.7-1.3 \mathrm{~mm}$ in width) that were arranged in long, sublinear chains that coalesced in cross-, T-, or L-shape, which is characteristic for Entobia cateniformis Bromley and D'Alessandro, 1984 in the late ontogenetic growth phase C. This system formed one tier in about $0.1-0.2 \mathrm{~mm}$ depth in the block parallel to the external surface, extending through the entire block.

In the 3-year block, an early stage of Entobia megastoma (Fischer, 1868) was found. It was composed of a sublinear gallery (about $50 \times 4 \mathrm{~mm}$ in size) with hand-like extensions

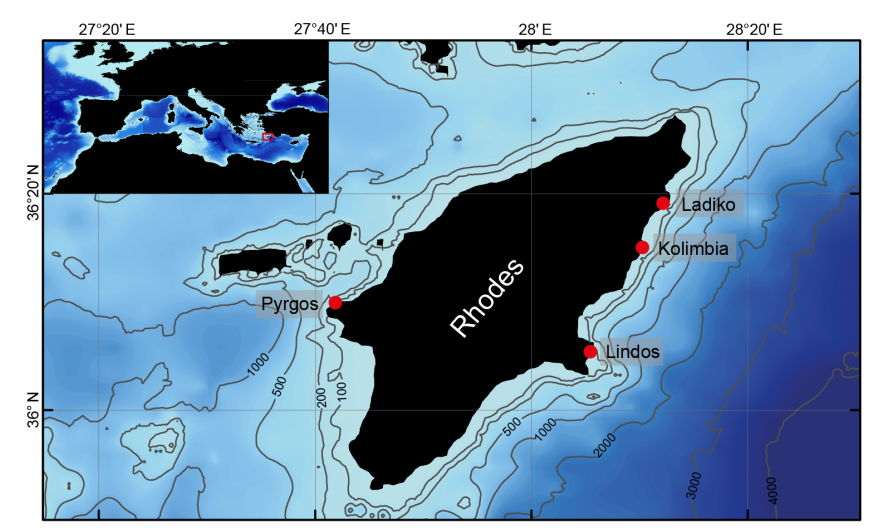

Figure 1. Location of the long-term experiment at Rhodes, Greece, in the Eastern Mediterranean Sea. Between 1982 and 1996, experimental blocks were deployed at four sites on the eastern and western coast of Rhodes in 3 to $17 \mathrm{~m}$ water depth. Bathymetric data were derived from the EMODnet Portal for Bathymetry (EMODnet, 2015).

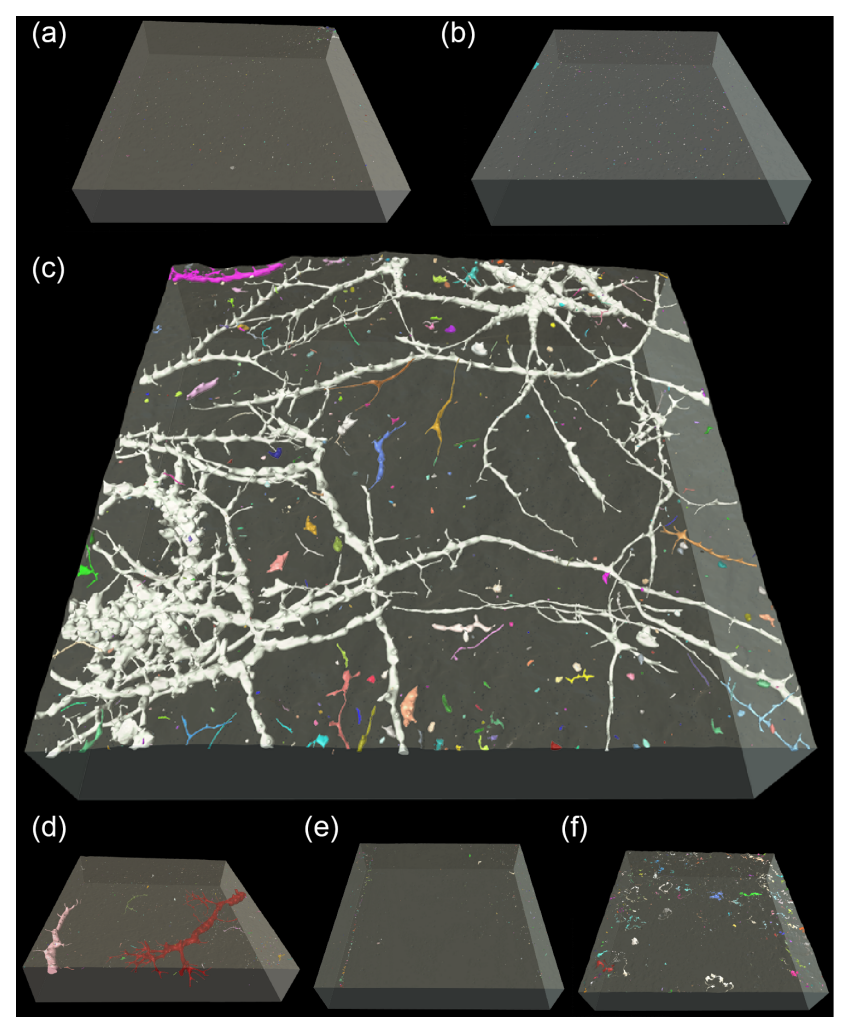

Figure 2. Micro-computed tomographic visualisation of bioerosion traces in experimental blocks deployed for 1-4 years. (a-b) The 1 -year blocks showed no macrobioerosion traces. First bioerosion traces were observed (c) in the 2-year block with Entobia cateniformis and (d) in the 3-year block with E. megastoma. (e-f) The 4-year blocks showed no distinct macrobioerosion traces (size of blocks $=90 \times 90 \times 18 \mathrm{~mm}$ ). 
Table 2. Inventory of bioerosion traces. Sponge borings (trace is Entobia ispp.) and boring sponges (trace maker is Cliona spp.) in the scanned experimental blocks were assigned via spicule analysis. Ontogenetic phases of sponge boring traces were determined according to Bromley and D'Alessandro (1984) with most mature stages in brackets. Measurements of sponge spicules are given as ranges, with length before widths, and means in parenthesis. Number of tylostyles is $n=20$ and number of spirasters is $n=5$ unless otherwise indicated in square brackets.

\begin{tabular}{|c|c|c|c|c|c|c|c|}
\hline $\begin{array}{l}\text { Exposure } \\
(\mathrm{yr})\end{array}$ & Boring & & Phase & Producer & & $\begin{array}{l}\text { Tylostyles } \\
(\mu \mathrm{m})\end{array}$ & $\begin{array}{l}\text { Spirasters } \\
(\mu \mathrm{m})\end{array}$ \\
\hline 2 & Entobia cateniformis & Fig. 2c & C (D) & Cliona schmidtii & Fig. 6a & $170-247(198) \times 3-8(5)$ & $\begin{array}{l}\text { (a) } 57-71(66) \times 2-3(2) \\
\text { (b) } 28-52(36) \times 2-3(3) \\
\text { (c) } 17 \times 3[1]\end{array}$ \\
\hline 3 & Entobia megastoma & Fig. 2d & A-B (D) & Sponge & - & - & - \\
\hline 5 & $\begin{array}{l}\text { Entobia geometrica } \\
\text { Caulostrepsis isp. }\end{array}$ & $\begin{array}{l}\text { Fig. 3a } \\
\text { Fig. 3A1-A3 }\end{array}$ & $\mathrm{D}(\mathrm{D})$ & $\begin{array}{l}\text { Cliona } \text { cf. celata } 1 \\
\text { Worm }\end{array}$ & Fig. 6c & $243-373(320) \times 6-13(10)$ & - \\
\hline 6 & Entobia cf. ovula & Fig. $3 b$ & $\mathrm{D}(\mathrm{D})$ & Cliona $\mathrm{cf}$. viridis & Fig. 6h & $217-356(273) \times 3-6(4)$ & $20-32 \times 1[2]$ \\
\hline 7 & Entobia cf. mammilata & Fig. $4 \mathrm{a}$ & A-B (E) & Sponge & - & - & - \\
\hline \multirow[t]{3}{*}{7} & Entobia megastoma & Fig. 4B1 & $\mathrm{B}-\mathrm{C}(\mathrm{D})$ & Cliona cf. celata 2 & Fig. 6d & $218-369(316) \times 4-8(6)$ & - \\
\hline & Entobia megastoma & Fig. 4B2 & $\mathrm{B}(\mathrm{D})$ & Cliona cf. celata 2 & Fig. 6e & $208-339(283) \times 3-9(6)$ & - \\
\hline & Entobia mammilata & Fig. 4B2 & $\mathrm{B}(\mathrm{E})$ & Sponge & - & - & - \\
\hline \multirow[t]{2}{*}{7} & Entobia mammilata & Fig. 4C1 & $\mathrm{D}(\mathrm{E})$ & Cliona $\mathrm{cf}$. viridis & Fig. 6g & $234-394(324) \times 4-9(7)$ & $\begin{array}{l}\text { (a) } 30-44(35) \times 1-2(1) \\
\text { (b) } 18 \times 1[1]\end{array}$ \\
\hline & Entobia megastoma & Fig. 4C2 & B (D) & Cliona cf. celata 2 & Fig. 6f & $235-358(321) \times 5-9(7)$ & - \\
\hline \multirow[t]{3}{*}{8} & Entobia cf. ovula & Fig. 5A1 & $\mathrm{D}(\mathrm{D})$ & Cliona cf. schmidtii & Fig. 6b & $179-275(220) \times 3-6(5)$ & $\begin{array}{l}\text { (a) } 58-84(75) \times 1-2(2) \\
\text { (b) } 25-46(35) \times 2(2) \\
\text { (c) } 21 \times 7[1]\end{array}$ \\
\hline & Entobia cf. magna & Fig. 5A2 & B (D) & Cliona rhodensis & Fig. 6i & $245-356(289) \times 6-10(8)$ & $23 \times 1[1]$ \\
\hline & Entobia cf. parva & Fig. 5A3 & $\mathrm{D}(\mathrm{D})$ & Sponge & - & - & - \\
\hline $8-9$ & Entobia megastoma & Fig. $5 b$ & $\mathrm{~B}(\mathrm{D})$ & Sponge & - & - & - \\
\hline 14 & $\begin{array}{l}\text { Entobia cf. cretacea } \\
\text { Trypanites isp. }\end{array}$ & $\begin{array}{l}\text { Fig. } 5 c \\
\text { Fig. } 5 \mathrm{C} 3-\mathrm{C} 5\end{array}$ & C-D (D) & $\begin{array}{l}\text { Sponge } \\
\text { Worm }\end{array}$ & - & - & - \\
\hline
\end{tabular}

(phase A-B; Fig. 2d). In the two 4-year blocks no assignable macrobioerosion patterns occurred (Fig. 2e-f).

In the 5-year block, a well-developed Entobia geometrica Bromley and D'Alessandro, 1984 cavity network was detected (Fig. 3a). The trace consisted of subrectangular to subtriangular flattened chambers with rounded corners (about $3.5-9.9 \mathrm{~mm}$ in diameter) that were aligned in weakly developed rows (phase D). The system extended in one tier throughout the entire surface of the block, parallel to the substrate surface in about $0.2-0.5 \mathrm{~mm}$ depth. In addition, one early-stage and two well-developed specimens of the polychaete bioerosion traces Caulostrepsis isp. penetrated from the upper surface into the block (Fig. 3A1-A3).

In the 6-year block, a well-developed network of Entobia cf. ovula Bromley and D'Alessandro, 1984 occurred (Fig. 3b). The trace was characterised by globose-ovoid to sub-prismatic chambers (about $0.7-1.5 \mathrm{~mm}$ in diameter) that were arranged in a crowded boxwork pattern (phase D). The entire system had a diameter of $40-50 \mathrm{~mm}$ and was arranged in one tier parallel to the external substrate surface in about $0.2-0.6 \mathrm{~mm}$ depth.

In the 7-year block, the bioerosion intensity strongly varied within the three subsamples (Fig. 4a-c). In the first subsample only an early-stage sponge boring was found that resembled Entobia mammilata Bromley and D'Alessandro, 1984 in growth phases A-B (Fig. 4a). In the second subsample, two separate specimens of E. megastoma and one of E. mammilata occurred (Fig. 4b). The first specimen of E. megastoma was composed of subcylindrical galleries that formed a three-dimensional system $(30 \times 40 \mathrm{~mm})$ and penetrated about $1.5 \mathrm{~cm}$ into the substrate (phases $\mathrm{B}-\mathrm{C}$; Fig. 4B1). The second specimen of E. megastoma was connected with $E$. mammilata (Fig. 4B2). This specimen of $E$. megastoma appeared to be an earlier growth stage than the other specimens in the same block (phase B). Entobia mammilata formed chains of turnip-shaped chambers (about 1.3$1.7 \mathrm{~mm}$; in phase B). The galleries extended over an area of about $42 \times 40 \mathrm{~mm}$ and were arranged in two tiers in about $10 \mathrm{~mm}$ depth of the block. The third subsample was crowded with bioerosion traces that were identified as two entobian ichnospecies (Fig. 4c). Here, a well-developed network of $E$. mammilata was composed of clusters of tubercle-like chambers in about $1.2-1.4 \mathrm{~mm}$ of the block (phase D; Fig. 4C1). The network extended over an area of $30 \times 90 \mathrm{~mm}$ and had penetrated the entire depth of the block $(18 \mathrm{~mm})$. In addition, several juvenile specimens of E. megastoma occurred. The largest specimen was $25 \times 50 \mathrm{~mm}$ in size and had a subcylindrical gallery of about $3 \mathrm{~mm}$ in diameter with longexploratory threads (phase B; Fig. 4C2).

The 8-year block showed a dense network of shallow bioerosion (Fig. 5a), which was composed of three different entobians, dominated by a large network of $E$. cf. ovula clusters that were interconnected by long galleries in growth phase $\mathrm{D}$. The largest cluster was about $25 \times 40 \mathrm{~mm}$ in size and extended in about $0.2-0.6 \mathrm{~mm}$ depth of the block in one tier parallel to the external substrate surface (Fig. 5A1). In ad- 


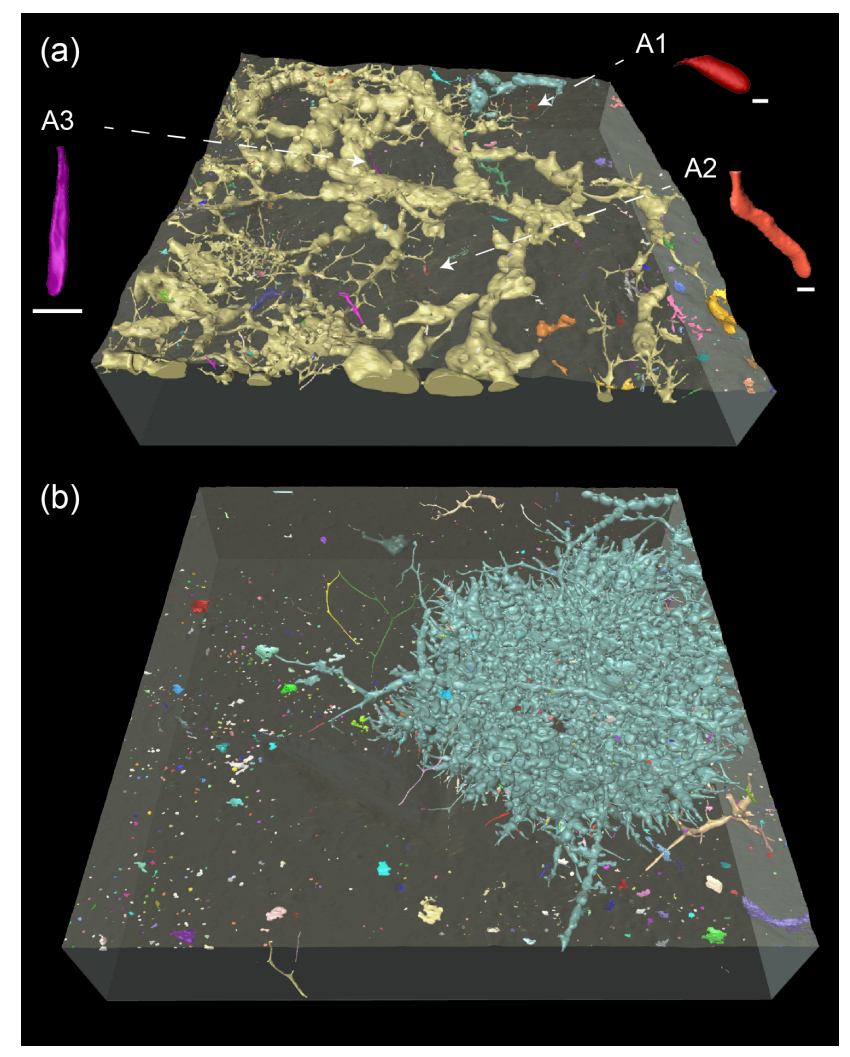

Figure 3. Micro-computed tomographic visualisation of bioerosion traces in experimental blocks deployed for 5-6 years. (a) The 5year block showed a network of Entobia geometrica and specimens of Caulostrepsis isp. (A1-A3). (b) The 6-year block showed a cluster of $E$. cf. ovula (scales A1-A3 $=2 \mathrm{~mm}$; size of blocks is $90 \times 90 \times 18 \mathrm{~mm})$.

dition, four large chambers of about $6 \mathrm{~mm}$ in diameter being connected by numerous exploratory threads were found that resembled E. magna Bromley and D'Alessandro, 1989 in phase B (Fig. 5A2). The third entobian was a specimen of Entobia cf. parva Bromley and D'Alessandro, 1989, which was identified through its compact boxwork of densely distributed, inflated chambers of about $0.2-0.6 \mathrm{~mm}$ that were arranged in a $15 \times 40 \mathrm{~mm}$ tier in about $10 \mathrm{~mm}$ depth of the block (phase D; Fig. 5A3).

In the 8- to 9-year block, an advanced network of $E$. megastoma and several scattered early-stage galleries cooccurred (Fig. 5b). The 1-4 mm subcylindrical galleries of the advanced specimen extended over an area of about $50 \times 90 \mathrm{~mm}$ and were distributed in parallel to the block surface (phase B). The smaller specimens were about 10$15 \mathrm{~mm}$ in size and formed characteristic hand-like cavities (phase A).

The 14-year block was extensively bioeroded and entobians difficult to separate (Fig. 5c). Several specimens of Entobia cf. cretacea Bromley, 1970 exhibited large polygonal chambers of about $1.3-4.2 \mathrm{~mm}$ in diameter, being con-

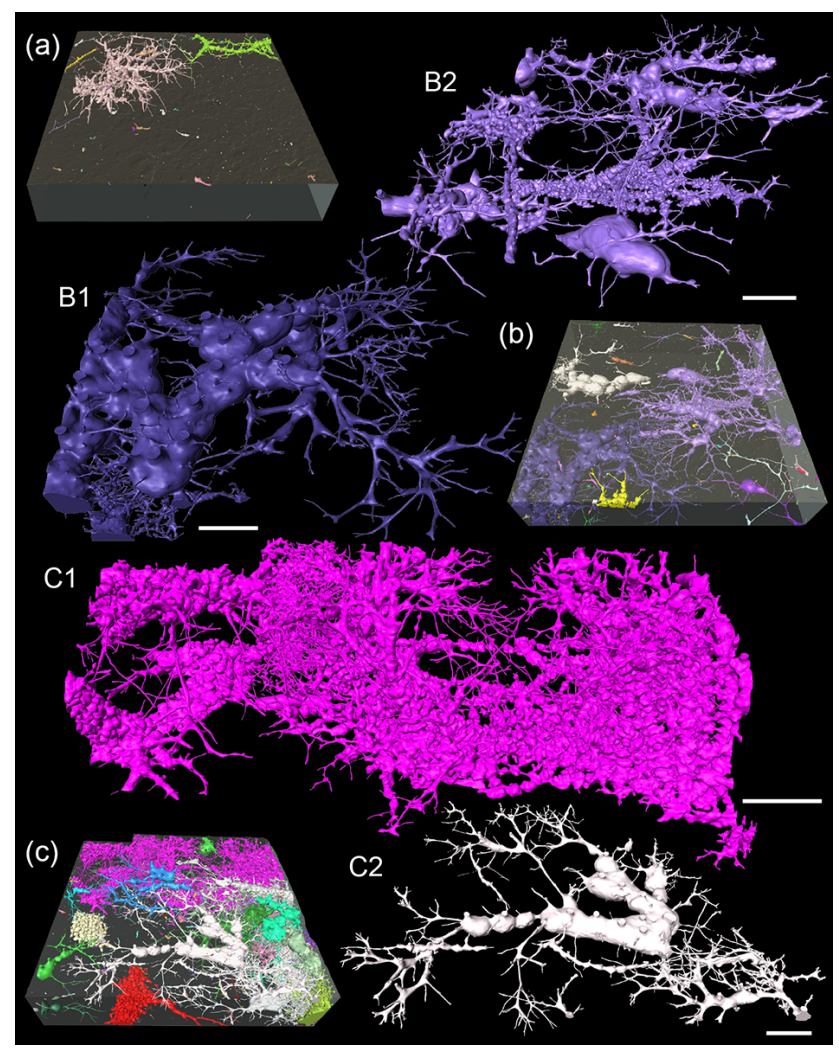

Figure 4. Micro-computed tomographic visualisation of bioerosion traces in three subsamples of the 7-year block. (a) First subsample of the block with Entobia cf. mammilata, (b) second subsample of the block showing two specimens of E. megastoma (B1 and large chambers B2) and E. mammilata (small chambers B2), and (c) third subsample of the block with E. mammilata $(\mathrm{C} 1)$ and E. megastoma (C2) $($ scales $=10 \mathrm{~mm}$; size of blocks is $90 \times 90 \times 18 \mathrm{~mm}$ ).

nected by numerous canals, and with the entobians extending through the entire depth of the block (18 mm; Fig. 5C1-C2). Bromley (1970) did not define distinct phases for E. cretacea, but we considered the detected traces to reflect phases $\mathrm{C}$ D. Apart from entobians, three galleries of the worm boring Trypanites isp. extended as slim sack-like cavities into the blocks (Fig. 5C3-C5). The software initially attributed these to the surrounding E. cretacea cavity network and the worm borings were afterwards separated manually from the sponge borings.

\subsection{Identification of boring sponges}

We recognised spicules of five clionaid bioeroding sponge species that could be assigned as trace makers of eight different entobians (Fig. 6, Tables 2, and Supplement Table S1). However, not from every cavity network spicules could be extracted, and other, rare, broken, or non-diagnostic spicules occurred that could not conclusively be matched to smaller entobians or used to identify bioeroding sponges at species 


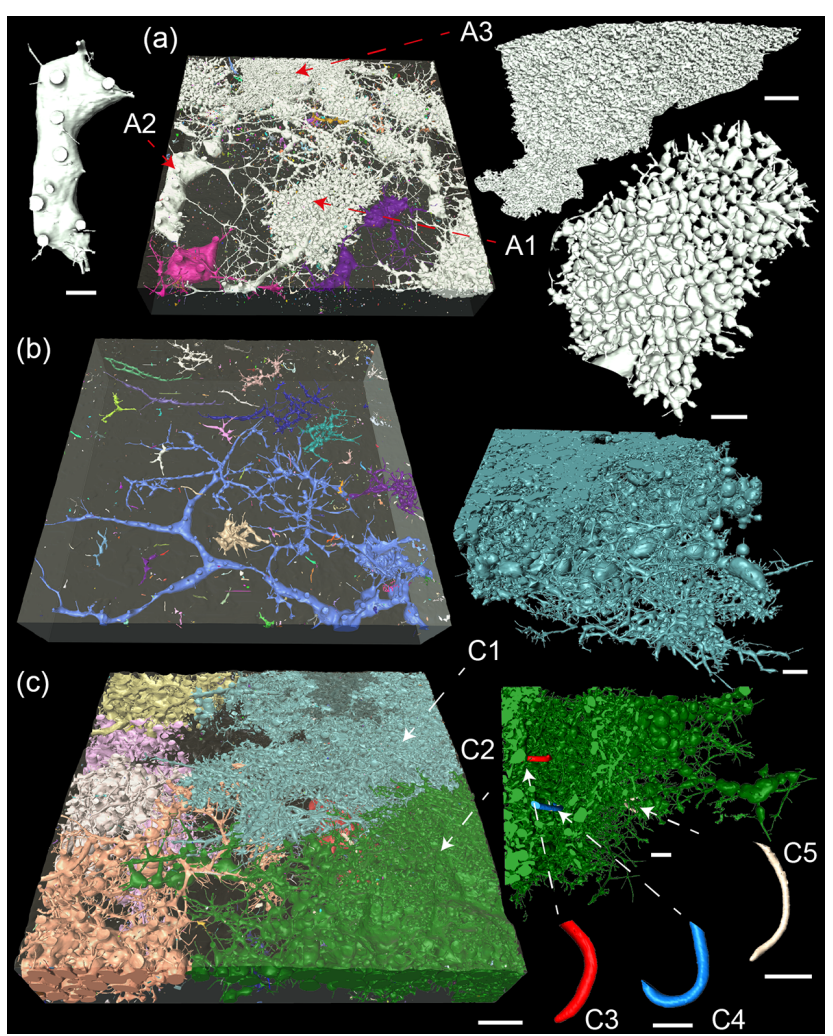

Figure 5. Micro-computed tomographic visualisation of bioerosion traces in experimental blocks deployed for 8-14 years. (a) 8-year block with Entobia cf. ovula (A1), E. magna (A2), and E. cf. parva (A3); (b) 8-9-year block with E. megastoma; and (c) 14-year block with $E$. cf. cretacea $(\mathrm{C} 1-\mathrm{C} 2)$ and Trypanites isp. (C3-C5) (scales $\mathrm{A} 1-\mathrm{A} 3, \mathrm{C} 1-\mathrm{C} 2=5 \mathrm{~mm}$; scales $\mathrm{C} 3-\mathrm{C} 5=1 \mathrm{~mm}$; size of blocks is $90 \times 90 \times 18 \mathrm{~mm})$.

level (these possibly included spicules from the genera $P i$ one, Cliothosa, Spirastrella, Siphonodictyon, and Thoosa).

Cliona schmidtii (Ridley, 1881) was recognised as the trace maker of E. cateniformis and E. ovula in the 2-year and the 8-year blocks (Fig. 6a-b, Table 2). Even when dry, the sponge tissue retained its characteristic purple colour that was an immediate indicator for $C$. schmidtii. Tylostyles were $170-275 \mu \mathrm{m}$ in length and $3-8 \mu \mathrm{m}$ in thickness and had a slightly bent shaft. A spectrum of spiraster sizes was observed: we distinguished (i) relatively thin and long spirasters with small spines distributed along the convex sides of the helical shaft (axis 57-84 $\mu \mathrm{m}$ in length and $1-3 \mu \mathrm{m}$ in thickness), (ii) relatively short and thick spirasters with conical spines (axis $25-52 \mu \mathrm{m}$ in length and $2-3 \mu \mathrm{m}$ in thickness), and (iii) short, thick amphiaster-like spirasters (axis $17-21 \mu \mathrm{m}$ in length and 3-7 $\mu \mathrm{m}$ in thickness).

Two morphospecies of Cliona cf. celata Grant, 1826 were distinguished as trace makers of two different entobians. Cliona cf. celata 1 was trace maker of E. geometrica in the 5-year block (Fig. 6c, Table 2), and Cliona cf. celata 2 was matched to E. megastoma in the 7-year block (Fig. 6d-f, Ta-

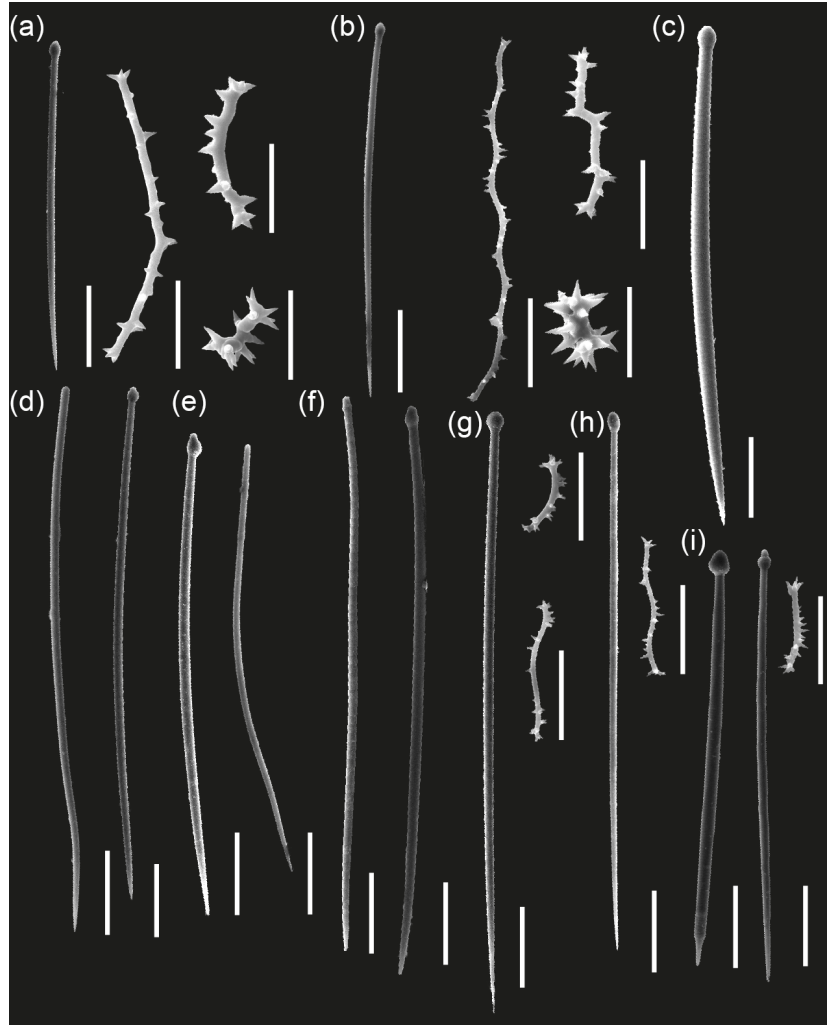

Figure 6. Spicules of boring sponges extracted from sponge tissue preserved in cavity networks in the scanned blocks. (a-b) Tylostyles and spirasters of Cliona schmidtii, (c) tylostyles of C. cf. celata 1 , (d-f) tylostyles of $C$. cf. celata 2, (g-h) tylostyles and spirasters of $C$. cf. viridis, and (i) tylostyles and spirasters of $C$. rhodensis (Fig. 5A2) (scales: tylostyles $=50 \mu \mathrm{m}$, spirasters $=20 \mu \mathrm{m}$ ).

ble 2). Both morphospecies had brown dry sponge tissue and exclusively tylostyles. Tylostyles of C. cf. celata 1 were 243 $373 \mu \mathrm{m}$ in length and $6-13 \mu \mathrm{m}$ in thickness, were comparatively robust with well-formed tyles that were occasionally subterminal, and had mostly straight or subtly bent shafts. Tylostyles of $C$. cf. celata 2 were comparatively slim, often with subterminal, occasionally multiple, tyles (tyles could be strongly displaced or weakly pronounced) and occasional near-stylar modifications occurred. The tylostyle shafts of C. cf. celata 2 were occasionally flexuous, being on 208 $369 \mu \mathrm{m}$ in length but only about 3-9 $\mu \mathrm{m}$ in thickness.

Based on scarce spirasters, Cliona cf. viridis (Schmidt, 1862) was tentatively identified as trace maker of $E$. ovula and E. mammilata in the 6- and 7-year blocks (Fig. 6g-h, Table 2). The colour of the dry sponge tissue was brown. Tylostyles were $217-394 \mu \mathrm{m}$ in length and about 3-9 $\mu \mathrm{m}$ in thickness, fusiform, slightly bent and had round, oval, or subterminal tyles. Two types of spirasters were distinguished: (i) straight, $20-44 \mu \mathrm{m}$ in length and $1-2 \mu \mathrm{m}$ in thickness, with relatively long spines that were mainly clustered at the ends 

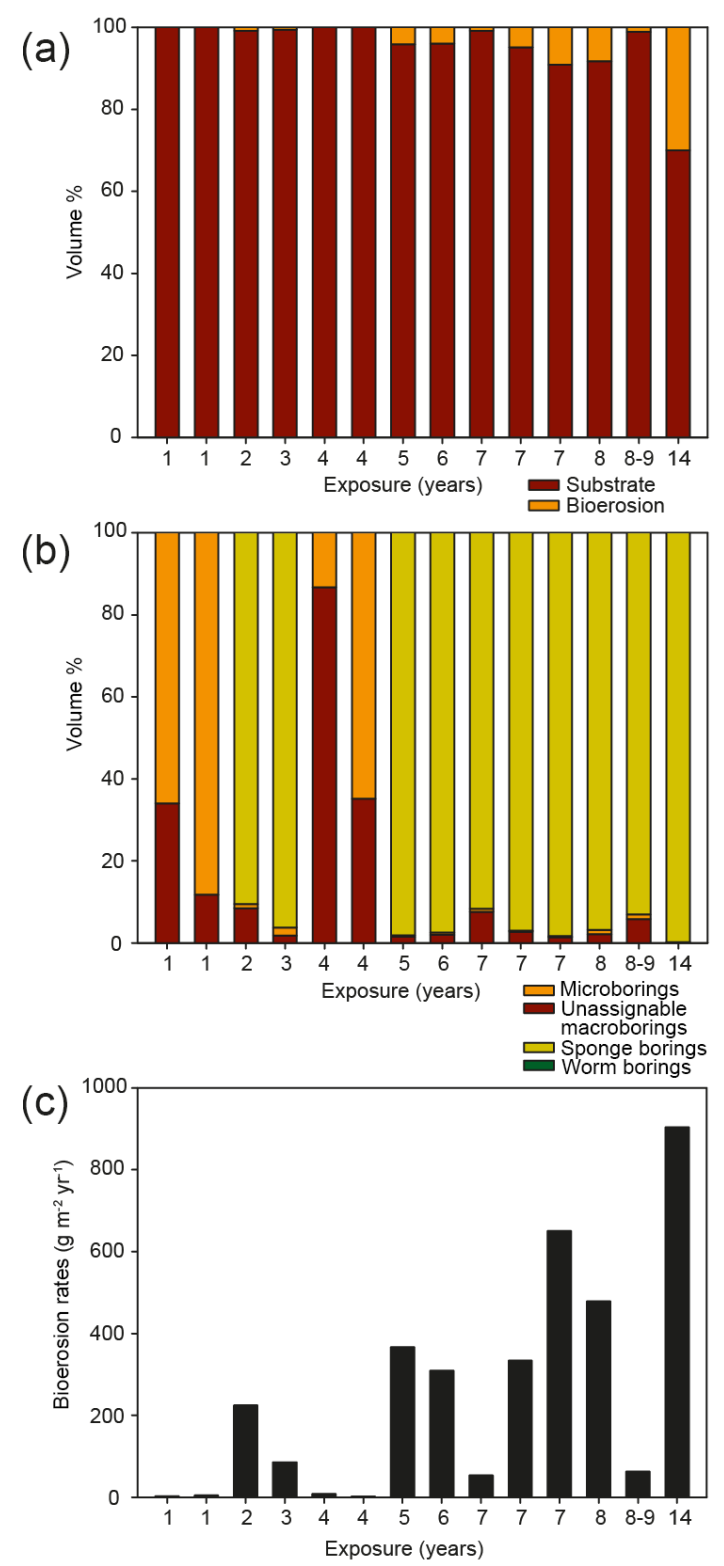

Figure 7. (a) Proportion of retained substrate vs. internal bioerosion in the scanned blocks, (b) proportional contribution of the different groups of boring organisms to the internal bioerosion in A, and (c) internal bioerosion rates $\left(\mathrm{g} \mathrm{m}^{-2} \mathrm{yr}^{-1}\right)$ measured in experimental substrates during the experiment.

of the shaft; and (ii) helical, $18 \mu \mathrm{m}$ in length and $1 \mu \mathrm{m}$ in thickness, with small spines.

Cliona rhodensis Rützler and Bromley, 1981 was identified as trace maker of E. magna in the 8-year block (Fig. 6i, Table 2). The colour of the dry sponge tissue was brown. Tylostyles were near straight and fusiform, $245-356 \mu \mathrm{m}$ in length and about 6-10 $\mu \mathrm{m}$ in thickness, and had distinct tyles. Only one complete, undamaged spiraster was found, which was $23 \mu \mathrm{m}$ in length and $1 \mu \mathrm{m}$ in thickness and had discrete, relatively long spines slightly recurving at their tips.

\subsection{Bioerosion intensity and rates}

Quantification of bioerosion in the experimental blocks revealed that in blocks deployed for 1 to 4 years only small volumes of substrate were removed by bioerosion $(<1 \%$; Fig. 7a, Table S2). In the 5- to 8-year blocks, the volume of bioerosion increased to 4-9\%. The highest bioerosion intensity was measured in the block that was deployed for 14 years (30\%).

With respect to the proportional contribution of the different groups of bioeroding organisms to total bioerosion, the largest part of bioerosion in the 1- and 4-year blocks was represented by microbioerosion and unassignable macrobioerosion patterns (Fig. 7b). In all other blocks, bioerosion was predominantly produced by boring sponges. Only in the 5and 14-year blocks complementary worm bioerosion was observed, but it contributed less than $1 \%$ to the total volume of bioerosion.

Analogous to the gradual increase in total volume of bioerosion, total bioerosion rates (i.e. residual micro- and macrobioerosion) increased with exposure time (Fig. 7c, Table S2). Lowest values were found in the 1- to 4-year blocks $\left(1.5-85 \mathrm{~g} \mathrm{~m}^{-2} \mathrm{yr}^{-1}\right)$, except in the 2-year block, where bioerosion rates tallied with $224 \mathrm{~g} \mathrm{~m}^{-2} \mathrm{yr}^{-1}$. In the 5- to 7year blocks bioerosion was elevated compared to blocks retrieved after shorter periods and reached values of 308$648 \mathrm{~g} \mathrm{~m}^{-2} \mathrm{yr}^{-1}$. However, in 7- and 8 to 9-year blocks lower values of 53 and $62 \mathrm{~g} \mathrm{~m}^{-2} \mathrm{yr}^{-1}$ were observed. Highest bioerosion rates were measured in the 14-year block, resulting in a maximum value of $900 \mathrm{~g} \mathrm{~m}^{-2} \mathrm{yr}^{-1}$. Overall, observed bioerosion patterns suggest that not only the bioerosion intensity, i.e. the absolute volume removed by bioerosion, but also the bioerosion rates, i.e. bioerosion normalised to a time span of 1 year, increased with time of exposure. An additional statistical evaluation was not considered feasible, however, due to the limited amount of available blocks suitable for micro$\mathrm{CT}$ analysis.

\section{Discussion}

\subsection{Micro-CT as a tool for the visualisation and quantification of internal macrobioerosion}

Methods used in this study represent a new approach and perspective for precise and automatic differentiation and quantification of internal structures of bioerosion, and they can be employed for similar aspects in biogeoscience research. Previously, evaluation of internal bioerosion by tomographic analysis was restricted to two-dimensional image analysis of consecutive layers (e.g. Becker and Reaka-Kudla, 1997; Hassan, 1998; Sammarco and Risk, 1990; Schönberg, 2001) and only recently included also three-dimensional measurement tools (Crook et al., 2013). Above methods are suitable for comparatively simple bioerosion structures but show clear 
limitations in the differentiation of complex cavity networks. In our study we took advantage of program algorithms that help to distinguish different traces. This function needs to be manually revised, however, as it does not automatically identify ichnotaxa according to morphological differences. This becomes especially clear where morphological distinct traces were identified as fused to one connected cavity network (Figs. 4B2, 5a), an effect likely caused by insufficient separation of traces due to different generations of endoliths overprinting earlier borings or galleries of bioeroding sponges that were produced by species or individuals living closely together (unlike observations in Bromley and Tendal, 1973).

Another restriction of micro-CT analysis is the correlation of sample size and spatial resolution. Based on the sample dimensions of $10 \times 10 \mathrm{~cm}$ spatial resolutions of $72 \mu \mathrm{m}$ were possible, which allowed preserving large cavity networks, as well as capturing thin exploratory threads of the sponges. However, where connecting galleries were near or below this resolution, occasionally different units of the same trace were split into apparently different specimens (Fig. 4c). Neither was the present resolution high enough to capture smaller microborings. Subsequent manual separation or joining of specimens needs to be assessed case by case. That is comparatively easy and feasible for cylindrical borings such as Trypanites isp. (Fig. 5C3-C5), but for complex cavity networks, such as sponge borings, this can potentially become very time consuming.

Apart from microborings and thin exploratory threads, a small proportion of deeper borings was also neglected due to the digital cropping of the blocks. In addition, some proportion of bioerosion became unavailable for quantification when grazers simultaneously removed surface layers and micro- as well as macrobioerosion traces within them. This substrate loss cannot be quantified without a reference that indicates the original thickness of the experimental blocks. What was actually measured, hence, is the residual internal bioerosion. Particularly in those blocks that were exposed long-term, bioerosion rates thus were somewhat underestimated, in turn implying that the observed increase in bioerosion rates can be expected to be even more pronounced for total bioerosion.

\subsection{The macrobioeroder community}

We distinguished $C$. cf. viridis, $C$. schmidtii, $C$. cf. celata morphospecies 1 and 2, and $C$. rhodensis as main producers of the observed bioerosion traces. When ignoring our second morphospecies of $C$. celata, the retrieved species represented $36 \%$ of the diversity of the locally reported Clionaidae, or $50 \%$ of the reported Cliona spp. for the Eastern Mediterranean (e.g. Evcen and Çinar, 2015; Vacelet et al., 2008). Apart from these, we assume that other sponges bioeroded the blocks as well, as evidenced by further rare spicules and by few traces that may have differed from the above, but from which no spicules could be extracted. This possibly includes
Cliothosa hancocki (Topsent, 1888), which was reported together with $C$. viridis and $C$. rhodensis to be one of the most abundant sponges at Rhodes (Rützler and Bromley, 1981).

Bioeroding sponge distributions and abundances, as well as their bioerosion rates, are dependent on environmental parameters such as water flow, nutrients, salinity, temperature, and light (see Schönberg (2008) for a review). Especially $C$. viridis and C. celata are very characteristic for the Mediterranean and known to be among the most abundant and destructive sponges in the Mediterranean Sea (e.g. Calcinai et al., 2011; Rosell et al., 1999). Both species, however, are difficult to identify and are members of species complexes that encompass very similar, but taxonomically different, species, which means that earlier accounts on their biology may refer to more than one species (e.g. Leal et al., 2016; Xavier et al., 2010). This may also be the case for $C$. schmidtii, because specimens from different sample sites can have somewhat different spicule morphologies (Christine Hanna Lydia Schönberg, personal observation). However, C. schmidtii and $C$. rhodensis were the presently best confirmed species, but little is known about their ecological requirements: both can be found in light and shade and both occur in moderately clear water and may avoid sedimentation (Carballo et al., 1994; Corriero et al., 2000; Rützler and Bromley, 1981), but it is not known what else characterises their ecological niches. To draw conclusions about environmental conditions from our data is difficult, because blocks were from different depths and current regimes, and the lack of replication prevented us from matching species distributions with environmental conditions.

In addition to environmental parameters, sponge bioerosion is sensitive to substrate characteristics such as lithology, density, porosity, crystal size, and the presence of siliciclastic fragments (e.g. Calcinai et al., 2007). During the experiment mostly marble blocks were used, but also two micritic limestone blocks: one 4-year block that showed no indication of macrobioerosion (Fig. 2e) and the 5-year block that was intensely bioeroded (Fig. 3a). Based on the present material, substrate effects cannot be ruled out, but they are difficult to identify and distinguish from environmental effects.

Although on the surrounding sea floor also boring bivalves and worms (sipunculans, polychaetes) were reported to be very common, our experimental blocks were dominated by boring sponges. Other long-term experiments in the tropics indicated a distinct succession of macroborers with polychaetes being present after a few months, while sponges and molluscs needed several years to establish (CarreiroSilva and McClanahan, 2012; Kiene and Hutchings, 1992, 1994; Osorno et al., 2005; Pari et al., 1998, 2002; PeyrotClausade et al., 1995). We assume that the dominance of sponges during the present study is an effect of the high spatial variability of macroborers and that locally sponges were most prevalent and determined the predominant larval supply. This assumption is in good agreement with results from other long-term experiments in the tropics, where macrobio- 
erosion strongly varied with water depth and nutrient supply (Carreiro-Silva and McClanahan, 2012; Kiene and Hutchings, 1992, 1994; Osorno et al., 2005; Pari et al., 1998, 2002; Peyrot-Clausade et al., 1995). The low occurrence of polychaete borings in the blocks may be also explained by the fact that polychaetes have comparatively short lifespans and that their vacant burrows became inhabited and overprinted by newly settled larvae of other boring species (Hutchings et al., 1992). To draw a direct comparison between bioerosion rates from these studies and our experiment, however, is difficult because these experiments were based on coral substrates and different quantification methods such as pointcounting of sections (Kiene and Hutchings, 1992, 1994) and image analysis of sections (Carreiro-Silva and McClanahan, 2012; Osorno et al., 2005; Pari et al., 1998, 2002).

\subsection{Palaeoenvironmental implications}

In the fossil record, sponge borings are preserved as trace fossils in calcareous hard substrates such as rocky shores, hardgrounds, or shells providing important information about palaeoenvironmental conditions (Wilson, 2007). Whereas recent boring sponges can be identified by their spicules or other morphological and molecular characters, the description of fossil entobians mostly relies on the morphological characterisation of their bioerosion traces. This is because the preservation potential of the boring is much higher than that of the siliceous spicules, which are only rarely preserved within the borings (e.g. Blissett et al., 2006; Bromley and Schönberg, 2008; Reitner and Keupp, 1991). Thus, in order to allow conclusions about past environmental conditions drawn in an actualistic approach from the ecophysiology studied in extant sponges, traces of recent sponges need to be matched with the sponge spicule record, so that deductions about fossil trace makers can be made where a close morphological resemblance is found between fossil and recent traces.

This study is one of the few that allowed matching sponge borings (bioerosion traces) and boring sponges (trace makers) by combining micro-CT with spicule analysis, providing respective information for five species of recent sponges. This information furthers an earlier detailed inventory of Mediterranean sponge borings and boring sponges by Bromley and D'Alessandro (1989). These authors were also able to obtain some clear matches between sponge species and ichnospecies, but in accordance with our results they also showed that one sponge species can produce different traces. Especially $C$. celata was described several times as producing traces that vary morphologically (Bromley and D'Alessandro, 1989; De Groot, 1977), E. geometrica and E. megastoma, even in the same type of substrate. However, as mentioned above, $C$. celata is not a single species but rather a species complex of several morphologically indistinct species, and a proper separation of species presently relies on molecular taxonomy (De Paula et al., 2012; Xavier et al., 2010). While spicular morphology can be variable with different environmental conditions (Bavestrello et al., 1993; Hoeksema, 1983; Rosell and Uriz, 1991), we recognised subtle but consistent differences in spicule morphology between $C$. cf. celata 1 (producing E. geometrica) and $C$. cf. celata 2 (producing $E$. megastoma), and in this case different traces may in fact represent different trace makers. A similar situation may be the case for the two borings found in the other difficult species, $C$. cf. viridis (E. ovula and E. mammilata) but, as present samples were not preserved for molecular analysis, we cannot confirm or reject this assumption.

In contrast to $C$. celata, we distinguished two different entobians for $C$. schmidtii: E. cateniformis and $E$. cf. ovula. Bromley and D'Alessandro (1989) also identified $C$. schmidtii as trace maker of $E$. ovula, but in their study $E$. cateniformis was produced by $P$. vastifica (formerly $C$. vastifica). We furthermore identified $C$. cf. viridis as trace maker for E. ovula and E. mammilata, which led to the conclusion that not only the same species can produce different traces, but the same trace can be produced by different species which is not a surprise but in accordance to basic ichnological principles (e.g. Bromley and Fürsich, 1980). Our results thus also agree with the assumption of Bromley and D'Alessandro (1984) that the morphology of entobians can strongly vary with the nature and structure of the substrate, the quality of the surrounding environment, the proximity of other endoliths, the species of the boring sponge, and the ontogeny of the borer. However, we lack comparative data as all presently available research on the correlation of sponge borings and boring sponges was carried out in Mediterranean Sea. Further studies are needed in order to ascertain whether the observed correlations also apply to different biogeographic realms and to better understand the application and limitations of sponge bioerosion traces as palaeoenvironmental indicators.

\subsection{Long-term succession of boring sponges: are 14 years long enough to develop equilibrium communities in a warm-temperate environment?}

This study provides one of the longest records for a bioerosion experiment and is one of the few available from the Mediterranean. It included quantitative analyses and observations on succession dynamics of macrobioeroders, all of which represents vital information to assess the impact of macrobioerosion on marine carbonate environments. Using the approach of micro-CT in combination with sponge spicule analysis revealed that during the experiment the blocks were predominantly bioeroded by sponges. The present study from a warm-temperate habitat confirms findings from tropical coral reefs that sponges require a few years to colonise newly available substrates and may only form larger infestations after more than 7 years (e.g. Kiene and Hutchings, 1992, 1994). Based on the present results and taking earlier macroscopic observations of the same blocks 
into account (Bromley et al., 1990), we recognised two developmental phases during our experiment: (1) an early community stage with initial sponge bioerosion and comparatively low macrobioerosion rates between years 1 and 5 and (2) an intermediate stage starting in year 6 or 7 when boring sponges become firmly established and bioerosion rates increase. Especially in the latter phase, our material displayed much variability, which we expect to decrease at later stages, when a mature bioeroding community (i.e. a fully developed bioeroding community of microborers, macroborers, and grazers also present in the ambient environment, with relatively stable bioerosion rates) has been established. Across the early and intermediate stages, bioerosion rates increased over time but can be expected to slow down to a relatively stable rate when equilibrium conditions are eventually reached. Based on the present data set, a sound prediction about the onset of these equilibrium conditions is not feasible and would require even longer exposures combined with a higher number of replicates; such experiments would be necessary to determine whether bioerosion rates peak at an equilibrium plateau or, more likely, that highest bioerosion rates are reached in the intermediate stage of colonisation, when substrate is not yet limited and competition not yet restricting further growth.

The analysis of ontogenetic stages of the observed entobians, nevertheless, suggests a distinct development of sponge bioerosion over time. Having settled down on suitable substrates and finding ample space, boring sponges can rapidly mature, preferentially by lateral extension. With more specimens colonising the blocks, boring sponges formed increasingly three-dimensional patterns but less developed ontogenetic stages. This is in good agreement with observations by Rützler (1975), who showed that with sufficient space and little competition, sponge borings mostly spread laterally and progressively bore vertically when the substrate edges are reached or lateral spreading is compromised by neighbouring competitors or other limitations. The presence of an increasing number of vertical borings during the intermediate stage in our experiment could indicate the gradual onset of a saturation phase. Similar observations with macrobioerosion rates proceeding at lower rates when free substrates became scarce and crowded with borings were demonstrated during long-term studies from the tropical realm (CarreiroSilva and McClanahan, 2012; Kiene and Hutchings, 1994; Lescinsky et al., 2008). At present, however, we cannot conclude how much time is needed in warm-temperate environments to reach equilibrium phases. This again underlines the necessity for further long-term studies, especially outside the tropical realm.

\section{Conclusions}

This study presents the first record on long-term bioerosion from the warm-temperate realm and showcases the use of
micro-CT to study internal bioerosion. In contrast to previous studies, experimental blocks were almost exclusively colonised by boring sponges, while only few worm and no bivalve borings were observed. Analyses of bioerosion traces and rates suggested an early community development stage during the first 5 years of exposure, where first boring sponges settle, but yield low rates of macrobioerosion, and an intermediate stage commencing in years 6 to 7 when boring sponges matured and bioerosion rates increase. After 14 years, $30 \%$ of the block volumes were occupied by boring sponges. Analysis of ontogenetic stages of sponge borings suggested that successful settlement of boring sponges is strongly dependent on the availability of space and on competition by other bioeroders. A high spatial variability in macrobioerosion prohibited clear conclusions about the onset of macrobioerosion equilibrium conditions. More longterm experiments are needed in order to identify equilibrium conditions and to assess the impact of macrobioerosion in different biogeographic realms.

\section{The Supplement related to this article is available online at doi:10.5194/bg-13-3461-2016-supplement.}

Acknowledgements. We thank Nicol Mahnken (Senckenberg am Meer) for technical support and Ines Pyko (Erlangen) for her help in inventorying the experimental blocks. This study was funded by the Deutsche Forschungsgemeinschaft (DFG Wi 3754/2-1). The publication of this article was funded by the open access fund of the Leibniz Association. The editor Hiroshi Kitazato, William Kiene, and an anonymous referee are acknowledged for valuable comments on the manuscript. This paper is published with the permission of the Director of the Institute of Geology and Mineral Exploration, Athens, Greece.

Edited by: H. Kitazato

\section{References}

Badde, A. and Illerhaus, B.: Three dimensional computerized microtomography in the analysis of sculpture, Scanning, 30, 16-26, 2008.

Baum, D. and Titschack, J.: Cavity and pore segmentation in 3D images with ambient occlusion, in: Proceedings of the 18th EG/VGTC Conference on Visualization, Groningen, the Netherlands, 6-10 June 2016.

Bavestrello, G., Bonito, M., and Sarà, M.: Influence of depth on the size of sponge spicules, Sci. Mar., 57, 415-420, 1993.

Becker, L. C. and Reaka-Kudla, M. L.: The use of tomography in assessing bioerosion in corals, in: Proceedings of the 8th International Coral Reef Symposium Vol. 2, Smithsonian Tropical Research Institute, Panama, 24-29 June 1996, 1819-1824, 1997. 
Beuck, L., Vertino, A., Stepina, E., Karolczak, M., and Pfannkuche, O.: Skeletal response of Lophelia pertusa (Scleractinia) to bioeroding sponge infestation visualised with micro-computed tomography, Facies, 53, 157-176, 2007.

Beuck, L., Wisshak, M., Munnecke, A., and Freiwald, A.: A giant boring in a Silurian stromatoporoid analysed by computer tomography, Acta Palaeontol. Pol., 53, 149-160, 2008.

Blissett, D. J., Pickerill, R. K., and Rigby, J. K.: A new species of boring sponge from the White Limestone Group, Jamaica, Caribb. J. Sci., 42, 247-251, 2006.

Bromley, R. G.: Borings as trace fossils and Entobia cretacea Portlock, as an example, Geol. J., 3, 49-90, 1970.

Bromley, R. G. and D'Alessandro, A.: Bioerosion in the Pleistocene of southern Italy: ichnogenera Caulostrepsis and Maeandropolydora, Riv. Ital. Paleontol. S., 89, 283-309, 1983.

Bromley, R. G. and D'Alessandro, A.: The ichnogenus Entobia from the Miocene, Pliocene and Pleistocene of southern Italy, Riv. Ital. Paleontol. S., 90, 227-296, 1984.

Bromley, R. G. and D'Alessandro, A.: Ichnological study of shallow marine endolithic sponges from the Italian coast, Riv. Ital. Paleontol. S., 95, 279-314, 1989.

Bromley, R. G. and Fürsich, F. T.: Comments on the proposed amendments to the International Code of Zoological Nomenclature regarding ichnotaxa, Z.N. (S.) 1973, B. Zool. Nomencl., 37, 6-10, 1980.

Bromley, R. G. and Schönberg, C. H.: Borings, bodies and ghosts: spicules of the endolithic sponge Aka akis sp. nov. within the boring Entobia cretacea, Cretaceous, England, in: Current Developments in Bioerosion, edited by: Wisshak, M. and Tapanila, L., Springer, Berlin, 235-248, 2008.

Bromley, R. G. and Tendal, O. S.: Example of substrate competition and phobotropism between two clionid sponges, J. Zool. Lond, 169, 151-155, 1973.

Bromley, R. G., Hanken, N.-M., and Asgaard, U.: Shallow marine bioerosion: preliminary results of an experimental study, B. Geol. Soc. Denmark, 38, 85-99, 1990.

Bromley, R. G., Beuck, L., and Ruggiero, E. T.: Endolithic sponge versus terebratulid brachiopod, Pleistocene, Italy: accidental symbiosis, bioclaustration and deformity, in: Current Developments in Bioerosion, edited by: Wisshak, M. and Tapanila, L., Springer, Berlin, 361-368, 2008.

Calcinai, B., Azzini, F., Bavestrello, G., Gaggero, L., and Cerrano, C.: Excavating rates and boring pattern of Cliona albimarginata (Porifera: Clionaidae) in different substrata, in: Porifera Research: Biodiversity, Innovation \& Sustainability, Proceedings of the 7th International Sponge Symposium, Búzios, Rio de Janeiro, 7-13 May 2006, 203-210, 2007.

Calcinai, B., Bavestrello, G., Cuttone, G., and Cerrano, C.: Excavating sponges from the Adriatic Sea: description of Cliona adriatica sp. nov. (Demospongiae: Clionaidae) and estimation of its boring activity, J. Mar. Biol. Assoc. UK, 91, 339-346, 2011.

Carballo, J. L., Sanchez-Moyano, J. E., and García-Gómez, J. C.: Taxonomic and ecological remarks on boring sponges (Clionidae) from the Straits of Gibraltar (southern Spain): tentative bioindicators?, Zool. J. Linn. Soc., 112, 407-424, 1994.

Carreiro-Silva, M. and McClanahan, T. R.: Macrobioerosion of dead branching Porites, 4 and 6 years after coral mass mortality, Mar. Ecol.-Prog. Ser., 458, 103-122, 2012.
Chazottes, V., Le Campion-Alsumard, T., Peyrot-Clausade, M., and Cuet, P.: The effects of eutrophication-related alterations to coral reef communities on agents and rates of bioerosion (Reunion Island, Indian Ocean), Coral Reefs, 21, 375-390, 2002.

Christomanos, A. A. and Norton, A. B.: Beiträge zur Kenntnis der Pigmente der Schwämme Aplysina aerophoba und Clione schmidtii, Folia Bioch. et Biol. Graeca, 11, 10-20, 1974.

Corriero, G., Scalera Liaci, L., Ruggiero, D., and Pansini, M.: The sponge community of a semi-submerged Mediterranean cave, Mar. Ecol., 21, 85-96, 2000.

Crook, E. D., Cohen, A. L., Rebolledo-Vieyra, M., Hernandez, L., and Paytan, A.: Reduced calcification and lack of acclimatization by coral colonies growing in areas of persistent natural acidification, P. Natl. Acad. Sci. USA, 110, 11044-11049, 2013.

DeCarlo, T. M., Cohen, A. L., Barkley, H. C., Cobban, Q., Young, C., Shamberger, K. E., Brainard, R. E., and Golbuu, Y.: Coral macrobioerosion is accelerated by ocean acidification and nutrients, Geology, 43, 7-10, 2015.

De Groot, R. A.: Boring sponges (Clinoidae) and their trace fossils from the coast near Rovinj (Yugoslavia), Geol. Mijnbouw, 56, 168-181, 1977.

De Paula, T. S., Zilberberg, C., Hajdu, E., and Lôbo-Hajdu, G.: Morphology and molecules on opposite sides of the diversity gradient: four cryptic species of the Cliona celata (Porifera, Demospongiae) complex in South America revealed by mitochondrial and nuclear markers, Mol. Phylogenet. Evol., 62, 529-541, 2012.

EMODnet Portal for Bathymetry, available at: http://www. emodnet-bathymetry.eu (last access: 6 June 2016), 2015.

Evcen, A., and Çinar, M. E.: Bioeroding sponge species (Porifera) in the Aegean Sea (Eastern Mediterranean), J. Black Sea/Mediterranean Environment, 21, 285-306, 2015.

Fang, J. K. H., Mello-Athayde, M. A., Schönberg, C. H. L., Kline, D. I., Hoegh-Guldberg, O., and Dove, S.: Sponge biomass and bioerosion rates increase under ocean warming and acidification, Glob. Change Biol., 19, 3581-3591, 2013.

Färber, C., Wisshak, M., Pyko, I., Bellou, N., and Freiwald, A.: Effects of water depth, seasonal exposure, and substrate orientation on microbial bioerosion in the Ionian Sea (Eastern Mediterranean), PLoS ONE, 10, e0126495, doi:10.1371/journal.pone.0126495, 2015.

Feldkamp, L. A., Davis, L. C., and Kress, J. W.: Practical conebeam algorithm, J. Opt. Soc. Am. A, 1, 612-619, 1984.

Fischer, P. M.: Recherches sur les éponges perforantes fossiles, Nouv. Arch. Mus. Hist. Nat. Paris, 4, 117-173, 1868.

Glynn, P. W.: Bioerosion and coral reef growth: a dynamic balance, in: Life and Death of Coral Reefs, edited by: Birkeland, C., Chapman and Hall, New York, 68-95, 1997.

Grange, J. S., Rybarczyk, H., and Tribollet, A.: The three steps of the carbonate biogenic dissolution process by microborers in coral reefs (New Caledonia), Environ. Sci. Pollut. Res. Int., 22, 13625-13637, 2015.

Grant, R. E.: Notice of a new zoophyte (Cliona celata, Gr.) from the Firth of Forth, Edinburgh New Phil. J., 1, 78-81, 1826.

Hassan, M.: Modification of carbonate substrata by bioerosion and bioaccretion on coral reefs of the Red Sea, Shaker Verlag, Aachen, 1998.

Hoeksema, B. W.: Excavation patterns and spiculae dimensions of the boring sponge Cliona celata from the SW Netherlands, Senck. Marit., 15, 55-85, 1983. 
Hutchings, P. A., Kiene, W. E., Cunningham, R. B., and Donnelly, C.: Spatial and temporal patterns of non-colonial boring organisms (polychaetes, sipunculans and bivalve molluscs) in Porites at Lizard Island, Great Barrier Reef, Coral Reefs, 11, 23-31, 1992.

Kennedy, E. V., Perry, C. T., Halloran, P. R., Iglesias-Prieto, R., Schönberg, C. H. L., Wisshak, M., Form, A. U., CarricartGanivet, J. P., Fine, M., Eakin, C. M., and Mumby, P. J.: Avoiding coral reef functional collapse requires local and global action, Curr. Biol., 23, 912-918, 2013.

Kiene, W. E.: A model of bioerosion on the Great Barrier Reef, Proceedings of the 6th International Coral Reef Symposium Vol. 3, Townsville, Australia, 8-12 August 1988, 449-454, 1988.

Kiene, W. E. and Hutchings, P. A.: Long-term bioerosion of experimental coral substrates from Lizard Island, Great Barrier Reef, Proceedings of the 7th International Coral Reef Symposium Vol. 1, UOG Station, Guam, 22-27 June 1992, 397-403, 1992.

Kiene, W. E. and Hutchings, P. A.: Bioerosion experiments at Lizard Island, Great Barrier Reef, Coral Reefs, 13, 91-98, 1994.

Le Campion-Alsumard, T.: Les cyanophycées endolithes marines. Systématique, ultrastructure, écologie et biodestruction, Oceanol. Acta, 2, 143-156, 1979.

Leal, C. V., De Paula, T. S., Lôbo-Hajdu, G., Schönberg, C. H. L., and Esteves, E. L.: Morphological and molecular systematics of the "Cliona viridis complex" from south-eastern Brazil, J. Mar. Biol. Assoc. UK, 96, 313-323, 2016.

Lescinsky, H. L., Hill, M., and Hoedt, B. A.: Results of long-term bioerosion study: Belize patch reefs, Proceedings of the 11th International Coral Reef Symposium, Ft. Lauderdale, Florida, 7-11 July 2008, 26-30, 2008.

Neumann, A. C.: Observations on coastal erosion in Bermuda and measurements of the boring rate of the sponge, Cliona lampa, Limnol. Oceanogr., 11, 92-108, 1966.

Osorno, A., Peyrot-Clausade, M., and Hutchings, P. A.: Patterns and rates of erosion in dead Porites across the Great Barrier Reef (Australia) after 2 years and 4 years of exposure, Coral Reefs, 24, 292-303, 2005.

Pari, N., Peyrot-Clausade, M., Le Campion-Alsumard, T., Hutchings, P., Chazottes, V., Golubic, S., Le Campion, J., and Fontaine, M. F.: Bioerosion of experimental substrates on high islands and on atoll lagoons (French Polynesia) after two years of exposure, Mar. Ecol.-Prog. Ser., 166, 119-130, 1998.

Pari, N., Peyrot-Clausade, M., and Hutchings, P. A.: Bioerosion of experimental substrates on high islands and atoll lagoons (French Polynesia) during 5 years of exposure, J. Exp. Mar. Biol. Ecol., 276, 109-127, 2002.

Peyrot-Clausade, M., Le Campion-Alsumard, T., Hutchings, P., LeCampion, J., Payri, C., and Fontaine, M.-F.: Initial bioerosion and bioaccretion on experimental substrates in high island and atoll lagoons (French Polynesia), Oceanol. Acta, 18, 531-541, 1995.

Rasband, W. S.: ImageJ. U. S. National Institutes of Health, Bethesda, Maryland, USA, http://imagej.nih.gov/ij/ (last access: 6 June 2016), 1997-2015.

Reitner, J. and Keupp, H.: The fossil record of the haplosclerid excavating sponge $A k a$ de Laubenfels, in: Fossil and Recent Sponges, edited by: Reitner, J. and Keupp, H., Springer, Berlin, 102-120, 1991.
Ridley, S. O.: Account of the zoological collections made during the surveys of the H. M. S. "Alert" in the Strait of Magellan and on the coast of Patagonia. Spongida, P. Zool. Soc. Lond., 107-139, 1881.

Rosell, D. and Uriz, M.-J.: Cliona viridis (Schmidt, 1862) and Cliona nigricans (Schmidt, 1862) (Porifera, Hadromerida): evidence which shows they are the same species, Ophelia, 33, 4553, 1991.

Rosell, D. and Uriz, M.-J.: Excavating and endolithic sponge species (Porifera) from the Mediterranean: species descriptions and identification key, Org. Divers. Evol., 2, 55-86, 2002.

Rosell, D., Uriz, M.-J., and Martin, D.: Infestation by excavating sponges on the oyster (Ostrea edulis) populations of the Blanes littoral zone (north-western Mediterranean Sea), J. Mar. Biol. Assoc. UK, 79, 409-413, 1999.

Rützler, K.: The role of burrowing sponges in bioerosion, Oecologia, 19, 203-216, 1975.

Rützler, K. and Bromley, R. G.: Cliona rhodensis, new species (Porifera: Hadromerida) from the Mediterranean, P. Biol. Soc. Wash., 94, 1219-1225, 1981.

Sammarco, P. W. and Risk, M. J.: Large-scale patterns in internal bioerosion of Porites: cross continental shelf trends on the Great Barrier Reef, Mar. Ecol.-Prog. Ser., 59, 145-156, 1990.

Schmidt, O: Die Spongien des adriatischen Meeres, Engelmann, Leipzig, 1862.

Schön, J.: Physical properties of rocks: a workbook, Handbook of Petroleum Exploration and Production, 8, Elsevier, Amsterdam, 2011.

Schönberg, C. H. L.: Estimating the extent of endolithic tissue of a Great Barrier Reef clionid sponge, Senck. Marit, 31, 29-19, 2001.

Schönberg, C. H. L.: A history of sponge erosion: from past myths and hypotheses to recent approaches, in: Current Developments in Bioerosion, edited by: Wisshak, M. and Tapanila, L., Springer, Berlin, 165-202, 2008.

Schönberg, C. H. L. and Shields, G.: Micro-computed tomography for studies on Entobia: transparent substrate versus modern technology, in: Current Developments in Bioerosion, edited by: Wisshak, M. and Tapanila, L., Springer, Berlin, 147-164, 2008.

Schönberg, C. H. L. and Wisshak, M.: Marine bioerosion, in: The Mediterranean Sea, edited by: Goffredo, S. and Dubinsky, Z., Springer, the Netherlands, 49-68, 2014.

Scott, P. J. B., Moser, K. A., and Risk, M. J.: Bioerosion of concrete and limestone by marine organisms: A 13 year experiment from Jamaica, Mar. Pollut. Bull., 19, 219-222, 1988.

Silbiger, N. J., Guadayol, Ò., Thomas, F. I. M., and Donahue, M. J.: Reefs shift from net accretion to net erosion along a natural environmental gradient, Mar. Ecol.-Prog. Ser., 515, 33-44, 2014

Silbiger, N. J., Guadayol, Ò., Thomas, F. I. M., and Donahue, M. J.: A novel $\mu \mathrm{CT}$ analysis reveals different responses of bioerosion and secondary accretion to environmental variability, PLoS ONE, 11, e0153058, doi:10.1371/journal.pone.0153058, 2016.

Stalling, D., Westerhof, M., and Hege, H.-C.: Amira: a highly interactive system for visual data analysis, in: The Visualization Handbook, edited by: Hansen, C. D. and Johnson, C. R., Elsevier Butterworth-Heinemann, Burlington, 749-767, 2005.

Titschack, J., Baum, D., De Pol-Holz, R., López Correa, M., Forster, N., Flögel, S., Hebbeln, D., and Freiwald, A.: Aggradation 
and carbonate accumulation of Holocene Norwegian cold-water coral reefs, Sedimentology, 62, 1873-1898, 2015.

Topsent, E.: Contribution à l'étude des Clionides, Arch. Zool. Exper. Gén., 5, 1-165, 1888.

Tribollet, A. and Golubic, S.: Cross-shelf differences in the pattern and pace of bioerosion of experimental carbonate substrates exposed for 3 years on the northern Great Barrier Reef, Australia, Coral Reefs, 24, 422-434, 2005.

Tribollet, A., Godinot, C., Atkinson, M., and Langdon, C.: Effects of elevated $p \mathrm{CO}_{2}$ on dissolution of coral carbonates by microbial euendoliths, Global Biogeochem. Cy., 23, GB3008, doi:10.1029/2008GB003286, 2009.

Tribollet, A., Radtke, G., and Golubic, S.: Bioerosion, in: Encyclopedia of Geobiology, edited by: Reitner, J. and Thiel, V., Springer, Dordrecht, 117-134, 2011.

Vacelet, J., Bitar, G., Dailianis, T., Zibrowius, H., and Perez, T.: A large encrusting clionaid sponge in the Eastern Mediterranean Sea, Mar. Ecol, 29, 237-246, 2008.

Vogel, K., Kiene, W. E., Gektidis, M., and Radtke, G.: Scientific results from investigation of microbial borers and bioerosion in reef environments, Göttinger Arb. Geol. Pal., Sb 2, 139-143, 1996.

Vogel, K., Gektidis, M., Golubic, S., Kiene, W. E., and Radtke, G.: Experimental studies on microbial bioerosion at Lee Stocking Island, Bahamas and One Tree Island, Great Barrier Reef, Australia: implications for paleoecological reconstructions, Lethaia, 33, 190-204, 2000.

Wilson, M.: Macroborings and the evolution of marine bioerosion, In: Trace fossils: Concepts, Problems, Prospects, edited by: Milller III, W., Elsevier, Amsterdam, 356-367, 2007.
Wisshak, M.: High-latitude bioerosion: The Kosterfjord experiment, Springer, Berlin, Heidelberg, 2006.

Wisshak, M.: Microbioerosion, in: Trace Fossils as Indicators of Sedimentary Environments, edited by: Knaust, D. and Bromley, R. G., Elsevier, Amsterdam, 213-243, 2012.

Wisshak, M., Form, A., Jakobsen, J., and Freiwald, A.: Temperate carbonate cycling and water mass properties from intertidal to bathyal depths (Azores), Biogeosciences, 7, 2379-2396, doi:10.5194/bg-7-2379-2010, 2010.

Wisshak, M., Tribollet, A., Golubic, S., Jakobsen, J., and Freiwald, A.: Temperate bioerosion: ichnodiversity and biodiversity from intertidal to bathyal depths (Azores), Geobiology, 9, 492-520, 2011.

Wisshak, M., Schönberg, C. H. L., Form, A., and Freiwald, A.: Ocean acidification accelerates reef bioerosion, PLoS ONE, 7, e45124, doi:10.1371/journal.pone.0045124, 2012.

Wisshak, M., Schönberg, C. H. L., Form, A., and Freiwald, A.: Effects of ocean acidification and global warming on reef bioerosion-lessons from a clionaid sponge, Aquat. Biol., 19, 111-127, 2013.

Wisshak, M., Schönberg, C. H. L., Form, A., and Freiwald, A.: Sponge bioerosion accelerated by ocean acidification across species and latitudes?, Helgoland Mar. Res., 68, 253-262, 2014.

Xavier, J. R., Rachello-Dolmen, P. G., Parra-Velandia, F., Schönberg, C. H. L., Breeuwer, J. A., and van Soest, R. W.: Molecular evidence of cryptic speciation in the "cosmopolitan" excavating sponge Cliona celata (Porifera, Clionaidae), Mol. Phylogenet. Evol., 56, 13-20, 2010. 